\title{
Development of Spray Schedules for Controlling Apple Scab in Uttarakhand
}

\author{
R. K. Prasad ${ }^{*}$, K. P. Singh ${ }^{2}$ and R. K. Gupta ${ }^{3}$ \\ ${ }^{1}$ College of Forestry, Ranichauri, Tehri Garhwal, Uttarakhand, India \\ ${ }^{2}$ Plant Pathology Division, GBPUA\&T, Pantnagar, U.S Nagar, Uttarakhand, India \\ ${ }^{3}$ Deparrtment of Botany, Banaras Hindu University, U.P, India \\ *Corresponding author
}

\section{Keywords}

Integrated spay schedules against, Flyspeck, Powdery mildew, Marsonina blotch and Apple scab disease

\section{Article Info}

Accepted: 24 September 2020 Available Online: 10 October 2020

\section{A B S T R A C T}

Apple scab caused by Venturia inaequalis (cke.) Wint is now prevalent in all the apple-growing region of India. It is serious in those areas which received good rainfall in spring and early summer months. Apple scab caused by Venturia inaequalis (cke.) Wint. is now prevalent in all the apple-growing region of India. It is serious in those areas which received good rainfall in spring and early summer months. The principles and methods of scab management are generally based on scab behavior. The knowledge of pre-disposing factors favorable to scab infection is pre-requisite for implementing the principles of control with prudence for effectivity. Protectant sprays are generally applied well after the infection has taken place but the symptoms are not manifested. The spray schedule would cover all stages viz., before, during and after infection and even the summer infection periods, Singh and Kumar, 2005. The stages of spray and choice of fungicides for application however are the cardinal factors determining the effectiveness of the control program, Singh and Kumar, 1999. Different management strategies have been developed to prevent the disease efficiently through 8-10 spray scheduled application of fungicides Gupta, 1985, Dar, et al., 1983; Singh and Kumar, 2005 besides, application of systemic and sterol inhibiting (SBI) fungicidal sprays depends on the prevailing weather conditions and competence of the producer. The cost of sprays accounts for 15-20 percent of the total maintenance expenditure on a tree. A spray schedules currently in vogue in Uttarakhand shall give insight of the strategy adopted to meet the disease challenge. Apple trees are attacked by a number of foliar diseases amongst which Scab, Marssonina blotch and Powdery mildew are foremost, apart from Sooty blotch and Fly speck which causes declining productivity of apple in this state. Powdery mildew (Podosphaera leucotricha (Ell. \& Ev.) E. S. Salmon) affects the terminal growth adversely and reduces photosynthesis, transpiration, and carbohydrate content of the host, tree vigor and blossom production (Singh, 2006). Marssonina blotch (Marssonina coronaria (Ell. \& J. J Davis) J. J Davis has been ravaging the apple plantations by causing mid-season defoliation (Sharma, 1999, 2001). Sooty blotch (Gloeodes pomigena (Schwein) Colby) and fly speck (Schizothyrium pomi (Mont. \& Fr.) Arx.) cause superficial greenish black blemishes and render the fruits unmarketable. The loss due to above these diseases results in reduction of yield, deterioration of fruit quality, devaluation of fruit, premature leaf fall and increase in operational expenses on account of fungicidal sprays as required for combating the diseases. It requires many applications of synthetic fungicides for the control of apple diseases. The usage of apple fungicides varies from country to country and is frequently changing. The sterol-biosynthesis inhibiting (SBI) fungicides are generally highly affective for control of most of the apple diseases In Uttarakhand, the orchardist conducting timely fungicidal sprays with various fungicides as recommended by the GBPUAT, Hill Campus, Ranichauri and department of Horticulture from time to time coupled with cultural operations like collection, and five per cent urea spray for burning of fallen leaves during autumn have been able to protect their crop from the diseases. In view of this, the present study was undertaken to: (1) develop a spray schedule involving commonly available systemic and non systemic fungicides (II) evolve new EBI fungicides in schedule to provide multi-disease control in the apple orchards. 


\section{Introduction}

Apple scab caused by Venturia inaequalis (cke.) Wint is now prevalent in all the applegrowing region of India. It is serious in those areas which received good rainfall in spring and early summer months. The disease was reported as first epiphytotic nature in 1869 in U. S. A. Though over a century has elapsed, the disease has not been eradicated form U.S. A. but has been kept under check that has involved heavy cost on account of spraying programmes (Schwinitz, 1834). Apple scab caused by Venturia inaequalis (cke.) Wint is now prevalent in all the apple-growing region of India. It is serious in those areas which received good rainfall in spring and early summer months. The principles and methods of scab management are generally based on scab behavior. The knowledge of predisposing factors favorable to scab infection is pre-requisite for implementing the principles of control with prudence for effectivity. Protectant sprays are generally applied well after the infection has taken place but the symptoms are not manifested. The spray schedule would cover all stages viz., before, during and after infection and even the summer infection periods, Singh and Kumar, 2005. The stages of spray and choice of fungicides for application however are the cardinal factors determining the effectiveness of the control program, Singh and Kumar, 1999. Different management strategies have been developed to prevent the disease efficiently through 8-10 spray scheduled application of fungicides Gupta, 1985, Dar, et al., 1983; Singh and Kumar, 2005 besides, application of systemic and sterol inhibiting (SBI) fungicidal sprays depends on the prevailing weather conditions and competence of the producer (Schewabe, 1980; Schewabe and Jones, 1983; Schwabe et al., 1984; Szkolnik, 1981; Thakur and Gupta, 1990a, b, 1992a; Singh and Kumar 1999). The cost of sprays accounts for 15-20 percent of the total maintenance expenditure on a tree. A spray schedules currently in vogue in Uttarakhand shall give insight of the strategy adopted to meet the disease challenge.

Apple trees are attacked by a number of foliar diseases amongst which Scab, Marssonina blotch and Powdery mildew are foremost, apart from Sooty blotch and Fly speck which causes declining productivity of apple in this state. Powdery mildew (Podosphaera leucotricha (Ell. \& Ev.) E. S. Salmon) affects the terminal growth adversely and reduces photosynthesis, transpiration, and carbohydrate content of the host, tree vigor and blossom production (Singh, 2006). Marssonina blotch (Marssonina coronaria (Ell. \& J. J Davis) J. J Davis has been ravaging the apple plantations by causing mid-season defoliation (Sharma, 1999, 2001). Sooty blotch (Gloeodes pomigena (Schwein) Colby) and fly speck (Schizothyrium pomi (Mont. \& Fr.) Arx.) cause superficial greenish black blemishes and render the fruits unmarketable. The loss due to above these diseases results in reduction of yield, deterioration of fruit quality, devaluation of fruit, premature leaf fall and increase in operational expenses on account of fungicidal sprays as required for combating the diseases. It requires many applications of synthetic fungicides for the control of apple diseases. The usage of apple fungicides varies from country to country and is frequently changing. The sterol-biosynthesis inhibiting (SBI) fungicides are generally highly affective for control of most of the apple diseases (Singh and Kumar 1999, Sharma and Verma, 2005). In Uttarakhand, the orchardist conducting timely fungicidal sprays with various fungicides as recommended by the GBPUAT, Hill Campus, Ranichauri and department of Horticulture from time to time coupled with cultural operations like collection, and five per cent urea spray for burning of fallen leaves during autumn have been able to 
protect their crop from the diseases. In view of this, the present study was undertaken to: (1) develop a spray schedule involving commonly available systemic and non systemic fungicides (II) evolve new EBI fungicides in schedule to provide multidisease control in the apple orchards.

\section{Materials and Methods}

The field trials were laid out on 8 to 10 year old Red and Royal Delicious apple trees naturally infected with $V$. inaequalis at the farmers orchards in the scab prone Harsil fruit belt (Village - Jochira, $2700 \mathrm{~m}$. asl) in Garhwal hills over three consecutive (2004, 2005, 2006) apple growing seasons (Fig. 1). Treatments were arranged in randomized block design with six blocks and ten trees per replication. A single tree for each replication was taken. Six spray schedules comprising of non-systemic and systemic fungicides (Table 1) along with a pre-leaf fall urea spray (5\%) were given at different phonological stages of the tree (Table 2). Water was sprayed on the control plants. The spraying of the fungicides was done with the help of "Maruti Foot Sprayer".

\section{Integrated spray schedules}

Consistent observations over the years on the maturity and discharged of ascospores and the occurrence of primary scab infection periods in higher elevations of Harsil indicated that potential of primary inoculum was more in the pink bud season, contrary to that in orchards at lower elevations in the state. Keeping that in view six different spray schedules were formulated and compared for their efficacy against various pathogens damaging the apple crop at an orchard located at $2700 \mathrm{~m}$. asl. Altitude. Various systemic, non-systemic and ergosterol biosynthesis inhibitor fungicides were rotated at different phonological stages of tree throughout the season. Each spray schedule was replicated ten times in randomized block design with single tree plots. Fungicides sprays were given at pink bud, petal fall, fruit set, fruit development (walnut size), fruit development I, fruit development II (40-45 days before harvest) with the last spray given at 20-25 days before harvest. A corresponding untreated control was also maintained on ten trees.

\section{Disease assessment}

The observations on the incidence of scab were observed after 21 days of the treatment. The key given by Croxall, et al., (1952) and modified by Gupta and Lele (1980a) was used for recording intensity of the disease on leaves. Data on primary scab incidence were taken on the basis of infection of ten leaves per spur out of a total of ten spurs per tree at fruit set stage. The percentage of leaves with secondary scab lesions was determined from all terminal leaves at pre-harvest stage on each of ten shoots per tree. The percentage of infected fruit was determined from 30 randomly selected fruits per tree. The appearance of all the five units was taken into account in assessing the percentage of scab on the tree as a whole. The scab severity was recorded from 0 to 5 scale $(0=$ No infection, $1=<5,2=75-10,3=>10-25,4=>25-$ $30,5=>50 \%$ area covered by spots on leaf or fruit).

Disease index $=\frac{\text { Class rating } \times \text { no of leaves } / \text { fruit in a particular class }}{\text { Total no. of leaves } / \text { fruit observed } \times \text { highest class rating }} \times 100$

\section{Powdery mildew}

Prevalence and intensity of apple powdery mildew was recorded at different intervals (Gupta et al., 1977; Singh, 2006). Prevalence was visually recorded by counting infection in twenty terminals on each tree and intensity was graded from 0 to 9 scale $(0=$ healthy, $9=$ 
over $75 \%$ leaf area mildewed). Disease index was calculated by the formula given by Gupta at al. (1977) as follow:

Disease index $=\frac{\text { Prevalence } \times \text { Intensity }(\%)}{100} \times 100$

\section{Marssonina blotch}

Observation on Marssonina blotch disease was recorded on twenty randomly selected whorls of older leaves in the lower portion of the tree at pre-harvest stage. Percentage disease incidence was calculated based on the number of leaves bearing blotch symptoms or defoliated leaves. The disease rating was done from 0 to 4 scale $(0=$ No spot, $4=$ more than 10 spot). In order to reduce the disease intensity complex to a single expression the following formula as suggested by McKinney (1923) was used

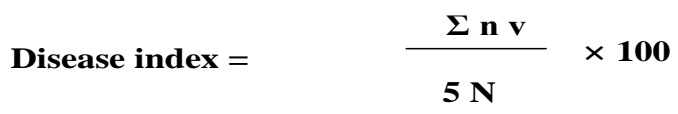

Where $\Sigma=$ Sum of the product, $\mathrm{n}=$ number of leaves with a particular disease rating, $\mathrm{v}=$ disease rating, $\mathrm{N}=$ total number of leaves under each treatment.

\section{Sooty blotch and flyspeck}

Percent disease was calculated by the following methods. Twenty fruits were selected randomly on each tree. The number of specks (colonies) of individual disease on fruits was counted and the mean was taken for calculating the percent disease.

$\begin{array}{cc}\text { Percent disease } & \text { Colonies } \\ 0.0 & 0 \\ 5.0 & 1 \\ 10.0 & 2 \\ 20.0 & 3 \\ 30.0 & 4 \\ 40.0 & 5 \\ 50.0 & 6 \text { or more }\end{array}$

Percent disease control was calculated by the formula given bellow:

Percent disease control= Percent infection in control - Percent infection in treatment $x$

Disease Index $\%=$ Class rating $\times \mathrm{N}_{0}$ of leaves $/$ fruit in particular class $\times 100$

Total no of leaves / fruits observed $x$ highest class rating

\section{Results and Discussion}

The intensity of apple scab can be substantially reduced by timely application of fungicides that are either protective, curative or have eradicant action against the pathogen. Such spray strategies are in popular use in all apple growing areas in India. All the six spray schedules provided reasonably good control of primary and secondary infection of scab. During all the three years, first ascospore maturity was recorded at the pink bud stage of the tree and the first spray in each of the treatment was given at this stage. These spray schedules are recommended at various susceptible phonological stage of apple tree. This suggested that fungicidal spray would provide a preventive measure to control the apple scab disease in those areas where it is being disseminated through airborne conidia.

Amongst different spray schedules tested at Jochira, Harsil during three years. Disease pressure was high in the orchard; over 75 percent scab incidence was recorded in leaves and fruits with a severity of over 40 percent. All spray schedules recorded significantly superior control as compared to untreated checks. Disease progressed at lower rate in the treated than untreated tree (Table 3). Two spray schedules, containing 6-7 fungicidal sprays were effective in giving complete control of the disease in fruit and above 70 percent control in leaves. The third spray schedule comprising sprays of carbendazim (25 gm), at pink bud stage followed by Thiophanate methyl (25 gm), Captan (300 gm), Mancozeb (300gm), and Hexaconazole (30 ml.), Carbendazim (25 gm) + Mancozeb 
(250 gm) with the last spray of Bitertanol (75 gm) was found quite effective against scab over leaves and fruit infection where it caused $73.71(\mathrm{~T}), 67.44(\mathrm{~L})$, and 68.10 (F) percent reduced in disease incidence while spray schedule first comprising the sequence of Thiophanate methyl (25 gm), followed by spray of carbendazim $(25 \mathrm{gm})+$ mancozeb (250 gm), myclobutanil (40 gm), mancozeb (300 gm), captan (300 gm), Hexaconazole (30 ml.), carbendazim (25 gm) was effective against leaf and fruit scab infection having $71.50(\mathrm{~T}), 66.49(\mathrm{~L})$, and 67.83 (F) percent reduction in disease incidence over untreated control, respectively (Figure 2). Summer progress of infection shows that the following spray schedules were effective in keeping the disease pressure minimum through the season even under heavy disease pressure Third spray schedules gave complete control of disease in terminal leaves $(72.88 \%)$ as well as fruits $(69.76 \%)$ throughout the season. Spray schedules III and I were rated at par in checking the scab rate during each year. The data on terminal, leaves and fruit disease incidence also indicate that spray schedules II gave least disease score followed by spray schedules IV, V, and VI (Figure 3).

\section{Integrated disease management (IDM)}

Scab: During the present study, all the spray schedules with 5 and 6 spraying per season provided significantly disease reduction in leaves and fruit when compare to untreated check. Disease symptoms were recorded on the leaves in the Ist week of May, which increased with time and the disease was maximum in the month of September. Spray schedules I and II were found to be the most effective as far as the ultimate scab control was concerned. In these spray schedules, early season spraying (Petal fall stage) could be avoided to accommodate more frequent fungicidal application late in the season. Spray schedule III was also the effective and economic, as only 5 spraying were given in the season during all the three years. The spray schedule comprising the spray of Thiophanate methyl + Mancozeb $(0.05+0.30$ $\%$ ) at pink bud stage followed by another five spray of Hexaconazole (0.03\%), Flusilazole (0.01 \%), Penconazole (0.05 \%), Carbendazim $(0.05 \%)$ and Captan $(0.30 \%)$ in order each after 25 days were found highly effective (Figure 4). It provided the maximum control of primary and secondary scab on leaves and fruit of apple. Spray schedules III was however, the least effective but better then locally available fungicides (systemic and non systemic schedule) against scab disease. It might be due to reduced number of spray (6 spraying) at only critical stage of scab development i.e. petal fall, fruit set, fruit development, 45-50 days before harvest and 20-25 days before harvest. It was therefore concluded that the apple scab spray schedule consisting of EBI fungicides was very effective in keeping this disease on leaves and fruits.

\section{Powdery mildew}

Spray schedules suggested that fungicidal spray would provide a preventive measure to control the powdery mildew of apple in those areas where it is being disseminated through airborne conidia. During all three years, first infection was recorded on terminal shoots at the silver tip to green tip stage of tree, and the first spray in each of the treatment were given at this stage. The observations on the incidence of powdery mildew were taken six times at 28 days interval of different phonological stage of tree. The disease appeared in the month of May where the disease index was 0.08 and it was maximum in July (0.43) and decreased thereon with rains in spray schedule VI. All the spray schedules recorded significant disease reduction on terminal shoot when compared to untreated checks. The mean disease index 
of spray schedules II and VI in the treated plants were $0.24,0.14$ percent in comparison to 0.62 in control thereby giving only 61.29 , 75.81 percent disease reduction. From these results it was concluded that apple scab spray schedules kept the powdery mildew under control but must be supplemented with at least one mildewcide at dormant or bud swell stage.

\section{Marssonina blotch}

All the spray schedules comprising EBI fungicides along with a pre leaf fall urea spray $(5 \%)$ were given per season at different phonological stage of the tree, provided reasonably good control of Marssonina blotch during 2004 to 2006. The results presented in which reveal that the leaf blotch diseases were reduced by $99.14,96.26$ percent in spray schedules II and VI in comparison to control. Leaf blotch disease appeared at $1^{\text {st }}$ week of June on untreated trees where the disease incidence was 12.45. The leaf blotch increased substantially with the advancement of phonological stage of trees. They were maximum in the month of September on both treated ( 0.32 and 2.85 disease incidence) and untreated (76.32 disease incidence) trees but the overall control was 99.58 percent indicating that the scab spray schedules VI is very effective in reducing their incidence thereby keeping fungal population at low level. All the six spray schedules recorded significant disease reduction in pre mature leaf fall when compared to untreated check. Of all apple scab spray schedules, six was the most effective followed by $2^{\text {nd }}$ for the control of pre mature leaf fall.

\section{Sooty blotch and fly speck}

Sooty blotch colonies appeared as shades of olive green and flyspeck as black spots on mature apple fruit. Both colonies commonly occurred on the same fruit, but the colonies are mutually exclusive. The observations were recorded three times on fruit development -I, fruit development- II and 20 days before harvest. These were found to be kept effectively under control by the scab spray schedules. The spray schedules VI was the most effective in control of sooty blotch and fly speck during all the three years at farmer fields, Jochira, Harsil. Six spray schedules containing 5 to 6 fungicidal sprays were effecting in giving complete control of both the diseases in fruits (more than 70 percent control). Spray schedules II were also the most effective and economic, as only 6 spraying were given in the season. Spray schedules VI recorded significant reduction in both, sooty blotch and fly speck by 97.85 and 98.11 percent respectively. Both the disease were observed at the end of July, August and September. Sooty blotch rose from 0.36 to 6.24 percent in treated trees and 4.68 to 42.83 percent in untreated trees whereas flyspeck rose from 0.12 to 2.15 in treated and 3.82 to 29.66 percent in untreated trees. All the six spray schedule recorded significant reduction in sooty blotch (85.43 to 97.05) and fly speck (92.75 to $98.11 \%$ ) over untreated control, respectively.

A protective spray programme being adopted in apple orchards in India includes 6 to 7 spray of non-systemic and systemic fungicides during the growing season and a single application of urea in autumn (Gupta, 1985; Gupta and Verma, 1988; Gupta and Thakur, 1992; Thakur and Sharma, 1999; Singh and Kumar, 1999). The first spray of protective fungicides must start at the green tip to pink bud stage. This spray is important to the high altitude area $(2700 \mathrm{~m}$. asl) because there are low temperature, afternoon mostly cloudy weather conditions, and early onset of season for the development of plant growth stage and release of primary inoculum. However, 2 or 3 sprays are required from bud break to petal fall to cover susceptible host 
tissues continuously. Thiophanate methyl, in a spray schedule, which recorded the lowest disease incidence and disease index, was very effective in checking primary infection on one-year growth. Singh et al., (1997) also obtained excellent control of primary infection with thiophanate methyl. Carbendazim and thiophanate methyl given as first spray in schedules I and III we showed acute fungi toxicity to primary infection of $V$. inaequalis. Similar observations have been recorded earlier by Singh and Kumar, (1999), Thakur and Gupta (1990b) and Hoch and Szkolnik (1979) on pre- symptom activity of these fungicides. It has been suggested that the protection of primary scab is more important to suppress the disease, therefore, by petal fall or later, if there are lesions of scab on the leaves and fruits, a spray of carbendazim or thiophanate methyl may be applied to inhibit the lesions and spore production. Thakur, (1992) and Dar et al., (1981) have reported usefulness of fungicides like Thiophanate methyl + Mancozeb Delan, Sylit, Captan, Bitertanol Bavistin, Benlate, Mancozeb + Sulphur, Chlorothalonil, and Ziram with in the country. Besides, Kloes et al., (1982), Turner and Sutton (1982), Ross (1982) and Jones et al., (1993) have also reported the usefulness of captan, baycor, fenarimol, sulfur and tebuconazole against apple scab disease. The results of this investigation are similar with the findings of the above workers in respect of most of the test fungicides.

Table.1 List of fungicides used in curative and protective spray programme in Harsil fruit belt during 2004-2006

\begin{tabular}{|l|c|l|l|}
\hline $\begin{array}{l}\text { Common name of } \\
\text { Fungicides }\end{array}$ & Concentration & Trade name & Manufactured \\
\hline $\begin{array}{l}\text { Flusilazole } \\
(40 \text { EC) }\end{array}$ & $0.01+0.02 \%$ & Nustar & Dupont, India Ltd. \\
\hline $\begin{array}{l}\text { Penconazole } \\
(10 \text { EC) }\end{array}$ & $0.05 \%$ & Topas & Syngenta, India Ltd. \\
\hline $\begin{array}{l}\text { Mancozeb } \\
(65 \text { WP) }\end{array}$ & $0.25 \%$ & Indofil, M-45 & Indofil, chemicals Ltd. \\
\hline $\begin{array}{l}\text { Defenconazole } \\
(25 \text { EC) }\end{array}$ & $0.015 \%$ & Score & Syngenta, India, Pvt. Ltd. \\
\hline $\begin{array}{l}\text { Hexaconazole } \\
(40 \text { EC) }\end{array}$ & $0.05 \%$ & Contaf/ Crizole & Syngenta, India Ltd. \\
\hline $\begin{array}{l}\text { Captan } \\
\text { (50 WP) }\end{array}$ & $0.20 \%$ & Captaf / Hexacap & Rallis, India Ltd. \\
\hline $\begin{array}{l}\text { Carbendazim } \\
(75 \text { WP) }\end{array}$ & $0.05 \%$ & Bavistine & BASF, India Ltd. \\
\hline $\begin{array}{l}\text { Thiophanate methyl } \\
(70 \text { WP) }\end{array}$ & $05 \%$ & Topsin-M & Rallies, India, Pvt. Ltd. \\
\hline $\begin{array}{l}\text { Chlorothalonil } \\
\text { (75 WP) }\end{array}$ & $0.04 \%$ & Kavach & Nevartis, India Ltd. \\
\hline $\begin{array}{l}\text { Fenarimole } \\
(25 \text { EC) }\end{array}$ & $0.05 \%$ & Rubigan & Dupont, India Ltd. \\
\hline Sulphur (80 WP) & $0.20 \%$ & Ansulf & Annu product, Ltd. \\
\hline $\begin{array}{l}\text { Myclobutanil } \\
\text { Bitertanol } \\
(25 \text { WP) }\end{array}$ & $0.04 \%$ & Systhane & Dow, Agro science, India, Pvt. Itd. \\
\hline & $0.075 \%$ & Baycor & Bayer, India Ltd. \\
\hline
\end{tabular}


Table.2 Spray schedules for control of apple scab at Jochira, Harsil fruit belt of Garhwal hills

\begin{tabular}{|c|c|c|c|c|c|c|c|}
\hline \multirow{2}{*}{$\begin{array}{l}\text { SI. } \\
\text { No }\end{array}$} & \multirow[t]{2}{*}{ Trees stage } & \multicolumn{6}{|c|}{ Spray schedules } \\
\hline & & $I$ & II & III & IV & $\mathbf{V}$ & VI \\
\hline 1 & Pink bud & $\begin{array}{c}\text { Thiophanate } \\
\text { methyl } \\
(50 \mathrm{~g})\end{array}$ & $\begin{array}{l}\text { Clorothalonil } \\
\text { (100g) }\end{array}$ & $\begin{array}{l}\text { Carbendazim } \\
\quad(25 \mathrm{gm})\end{array}$ & $\begin{array}{l}\text { Captan } \\
\qquad(300 g)\end{array}$ & $\begin{array}{c}\text { Captan } \\
(300 \mathrm{gm})\end{array}$ & $\begin{array}{l}\text { Mancozeb } \\
(300 \mathrm{gm})\end{array}$ \\
\hline 2 & Petal fall & $\begin{array}{c}\text { Carbendazim } \\
(25 \mathrm{~g})+ \\
\text { Mancozeb } \\
(250 \mathrm{~g})\end{array}$ & $\begin{array}{l}\text { Hexaconazole } \\
\quad(30 \mathrm{ml} .)\end{array}$ & $\begin{array}{c}\text { Thiophanate } \\
\text { methyl } \\
(50 \mathrm{gm})\end{array}$ & $\begin{array}{c}\text { Mancozeb } \\
(300 \text { gm })+ \\
\text { Sulphur }(200)\end{array}$ & $\begin{array}{l}\text { Bitertanol } \\
(75 \mathrm{gm})\end{array}$ & $\begin{array}{c}\text { Thiophanate methyl } \\
(25 \mathrm{~g}) \\
+ \\
\text { Mancozeb } \\
\text { (250 gm) }\end{array}$ \\
\hline 3 & $\begin{array}{l}\text { Fruit set } \\
\text { (Pea size) }\end{array}$ & $\begin{array}{l}\text { Myclobutanil } \\
(40 \mathrm{~g})\end{array}$ & $\begin{array}{l}\text { Mancozeb } \\
(300 \mathrm{gm})\end{array}$ & $\begin{array}{l}\text { Captan } \\
(300 \text { gm })\end{array}$ & $\begin{array}{l}\text { Bitertanol } \\
(75 \mathrm{gm})\end{array}$ & $\begin{array}{l}\text { Fenarimol } \\
\quad(40 \mathrm{ml})\end{array}$ & $\begin{array}{l}\text { Hexaconazole } \\
\quad(30 \mathrm{ml})\end{array}$ \\
\hline 4 & $\begin{array}{l}\text { Fruit } \\
\text { development } \\
\text { (Walnut size) }\end{array}$ & $\begin{array}{l}\text { Mancozeb } \\
(300 \mathrm{~g})\end{array}$ & $\begin{array}{l}\text { Carbendazim } \\
\quad(50 \mathrm{gm})\end{array}$ & $\begin{array}{c}\text { Mancozeb } \\
(200 \mathrm{gm}) \\
+ \\
\text { Sulfur } \\
(200 \mathrm{gm})\end{array}$ & $\begin{array}{c}\text { Carbendazim } \\
(25 \mathrm{~g})+ \\
\text { Mancozeb } \\
(250 \mathrm{gm})\end{array}$ & $\begin{array}{c}\text { Thiophanate } \\
\text { methyl } \\
(25 \text { gm }) \\
+ \\
\text { Mancozeb } \\
(250 \mathrm{gm})\end{array}$ & $\begin{array}{l}\text { Captan } \\
(300 \mathrm{gm})\end{array}$ \\
\hline 5 & $\begin{array}{l}\text { Fruit } \\
\text { development }\end{array}$ & $\begin{array}{l}\text { Captan } \\
\qquad(300 g)\end{array}$ & $\begin{array}{l}\text { Bitertanol } \\
\text { (75 gm) }\end{array}$ & $\begin{array}{l}\text { Hexaconazole } \\
\qquad(30 \mathrm{ml})\end{array}$ & $\begin{array}{c}\text { Thiophanate } \\
\text { methyl } \\
(50 \mathrm{gm})\end{array}$ & $\begin{array}{l}\text { Carbendazim } \\
\quad(50 \mathrm{gm})\end{array}$ & $\begin{array}{l}\text { Bitertanol } \\
(75 \mathrm{gm})\end{array}$ \\
\hline 6 & $\begin{array}{l}40-45 \text { days } \\
\text { before harvest }\end{array}$ & $\begin{array}{l}\text { Heaconazole } \\
\qquad(30 \mathrm{ml})\end{array}$ & $\begin{array}{l}\text { Hexaconazole } \\
\quad(30 \mathrm{ml}) \\
+ \\
\text { Clorothalonil } \\
\quad(100 \mathrm{gm})\end{array}$ & $\begin{array}{c}\text { Carbendazim } \\
(25 \mathrm{gm}) \\
+ \\
\text { Mancozeb } \\
\text { (250 gm }\end{array}$ & $\begin{array}{l}\text { Hexaconazole } \\
\qquad(30 \mathrm{ml})\end{array}$ & $\begin{array}{l}\text { Hexaconazole } \\
\qquad(30 \mathrm{ml})\end{array}$ & $\begin{array}{l}\text { Fenarimol } \\
(40 \mathrm{ml})\end{array}$ \\
\hline 7 & $\begin{array}{c}20-25 \text { days } \\
\text { before harvest }\end{array}$ & $\begin{array}{l}\text { Carbendazim } \\
(25 \mathrm{~g})\end{array}$ & $\begin{array}{l}\text { Mancozeb } \\
(300 \mathrm{gm})\end{array}$ & $\begin{array}{l}\text { Bitertanol } \\
(75 \mathrm{~m})\end{array}$ & $\begin{array}{l}\text { Carbendazim } \\
\qquad(25 \mathrm{~g})\end{array}$ & $\begin{array}{c}\text { Mancozeb } \\
(200 \mathrm{gm}) \\
+ \\
\text { Sulfur (200 gm) }\end{array}$ & $\begin{array}{l}\text { Mancozeb } \\
\text { (300 gm) }\end{array}$ \\
\hline
\end{tabular}


Table.3 Different spray schedules EBI tested for their efficacy in controlling apple scab disease at Jochira, Harsil fruit belt during 2004-2006

\begin{tabular}{|c|c|c|c|c|c|c|}
\hline \multirow[t]{2}{*}{ Tree stage } & \multicolumn{6}{|c|}{ Spray schedules } \\
\hline & $\mathbf{I}$ & II & III & IV & $\mathbf{V}$ & VI \\
\hline Pink bud & $\begin{array}{l}\text { Carbendazim } \\
(0.05 \%)\end{array}$ & $\begin{array}{c}\text { Thiophanate methyl } \\
(0.05 \%) \\
+ \\
\text { Mancozeb }(0.30 \%)\end{array}$ & - & $\begin{array}{c}\text { Thiophanate } \\
\text { methyl } \\
(0.05 \%)\end{array}$ & $\begin{array}{c}\text { Carbendazim }(0.05 \%) \\
+ \\
\text { Mancozeb }(0.30 \%)\end{array}$ & $\begin{array}{c}\text { Mancozeb } \\
(0.30 \%)\end{array}$ \\
\hline Petal fall & - & - & $\begin{array}{l}\text { Myclobutanil } \\
(0.04 \%)\end{array}$ & $\begin{array}{c}\text { Defenconazole } \\
(0.015 \%)\end{array}$ & - & $\begin{array}{l}\text { Hexaconazole } \\
(0.03 \%)\end{array}$ \\
\hline $\begin{array}{l}\text { Fruit-set } \\
\text { (Pea size) }\end{array}$ & $\begin{array}{c}\text { Flusilazole } \\
(0.01 \%)\end{array}$ & $\begin{array}{c}\text { Hexaconazole } \\
(0.03 \%)\end{array}$ & $\begin{array}{l}\text { Defenconazole } \\
\quad(0.015 \%)\end{array}$ & $\begin{array}{l}\text { Chlorothalonil } \\
(0.30 \%)\end{array}$ & $\begin{array}{c}\text { Penconazole } \\
(0.05 \%)\end{array}$ & $\begin{array}{c}\text { Penconazole } \\
(0.05 \%)\end{array}$ \\
\hline $\begin{array}{l}\text { Fruit } \\
\text { development } \\
\text { (Walnut size) }\end{array}$ & $\begin{array}{c}\text { Penconazole } \\
(0.05 \%)\end{array}$ & $\begin{array}{l}\text { Flusilazol } \\
(0.01 \%)\end{array}$ & - & $\begin{array}{l}\text { Hexaconazole } \\
\quad(0.03 \%)\end{array}$ & $\begin{array}{l}\text { Defenconazole } \\
\quad(0.015 \%)\end{array}$ & - \\
\hline $\begin{array}{l}\text { Fruit } \\
\text { development }\end{array}$ & $\begin{array}{c}\text { Mancozeb } \\
(0.30 \%) \\
+ \\
\text { Carbendazim } \\
(0.05 \%)\end{array}$ & $\begin{array}{c}\text { Penconazole } \\
(0.05 \%)\end{array}$ & $\begin{array}{c}\text { Flusilazole } \\
(0.01 \%)\end{array}$ & $\begin{array}{c}\text { Carbendazim } \\
(0.05 \%) \\
+ \\
\text { Mancozeb } \\
(0.30 \%)\end{array}$ & $\begin{array}{c}\text { Hexaconazole } \\
\quad(0.03 \%)\end{array}$ & $\begin{array}{l}\text { Defenconazole } \\
\quad(0.015 \%)\end{array}$ \\
\hline $\begin{array}{l}\text { 40-45, days } \\
\text { before harvest }\end{array}$ & $\begin{array}{l}\text { Bitertanol } \\
(0.075 \%)\end{array}$ & $\begin{array}{l}\text { Carbendazim } \\
(0.05 \%)\end{array}$ & $\begin{array}{c}\text { Mancozeb }(0.30 \%) \\
+ \\
\text { Sulphur }(0.20 \%)\end{array}$ & 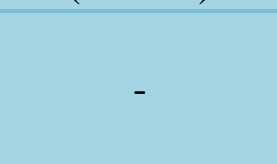 & $\begin{array}{c}\text { Flusilazole } \\
(0.01 \%)\end{array}$ & $\begin{array}{c}\text { Flusilazole } \\
(0.01 \%)\end{array}$ \\
\hline $\begin{array}{l}\text { 20-25, days } \\
\text { before harvest }\end{array}$ & $\begin{array}{c}\text { Mancozeb } \\
(0.30 \%)\end{array}$ & $\begin{array}{c}\text { Captan } \\
(0.30 \%)\end{array}$ & $\begin{array}{l}\text { Carbendazim } \\
(0.05 \%)\end{array}$ & $\begin{array}{c}\text { Chlorothalonil } \\
(0.30 \%)\end{array}$ & $\begin{array}{c}\text { Ziram } \\
(0.30 \%)\end{array}$ & $\begin{array}{c}\text { Thiophanate } \\
\text { methyl }(0.05 \%)\end{array}$ \\
\hline
\end{tabular}


Fig.1 Field view of experimental sites, a. Fruit set stage; b. Fruit development stage (Walnut size); c. 20 days before harvest
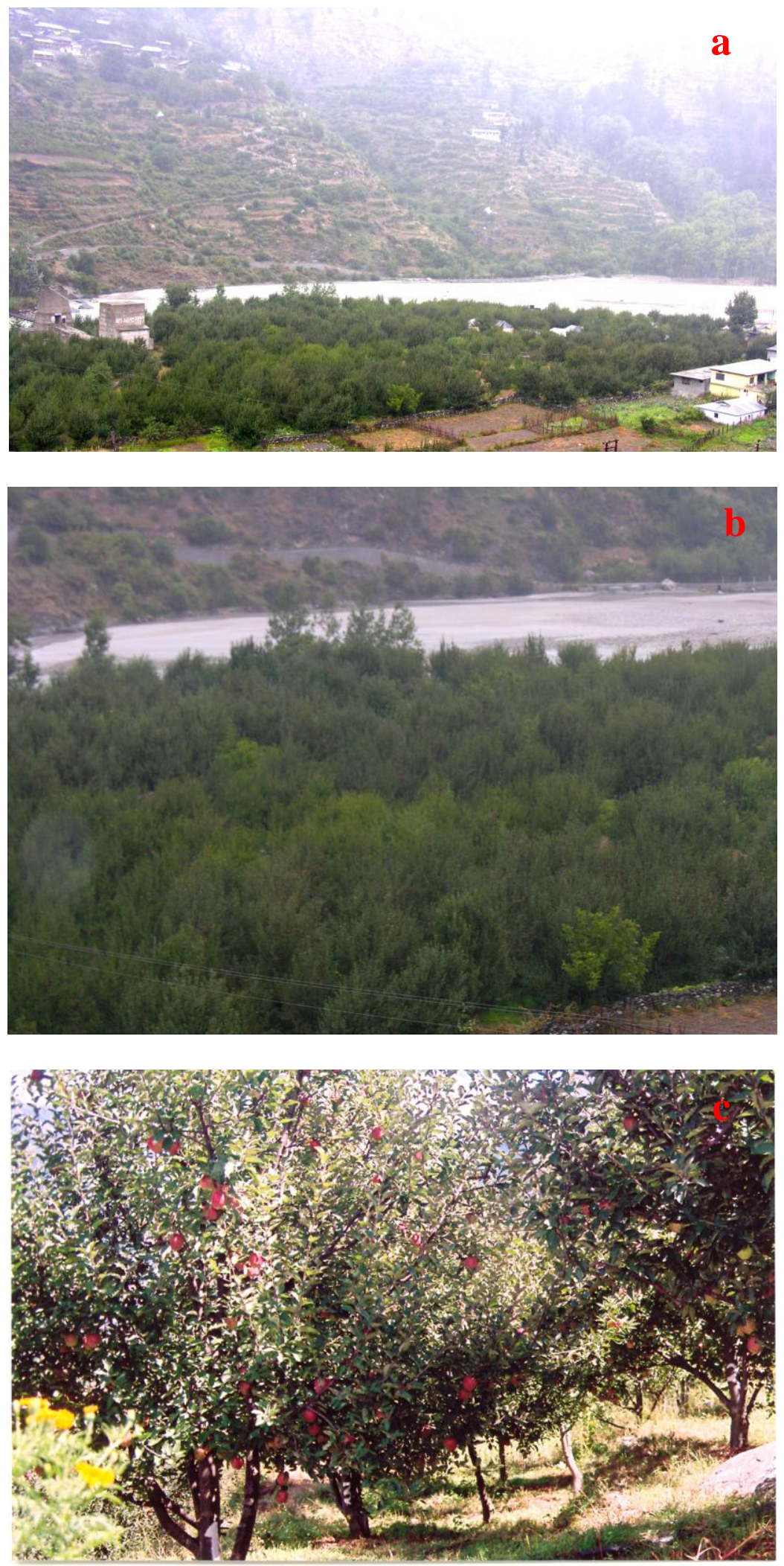
Fig.2 Efficacy of various fungicidal spray schedules against apple scab during 2004-2006

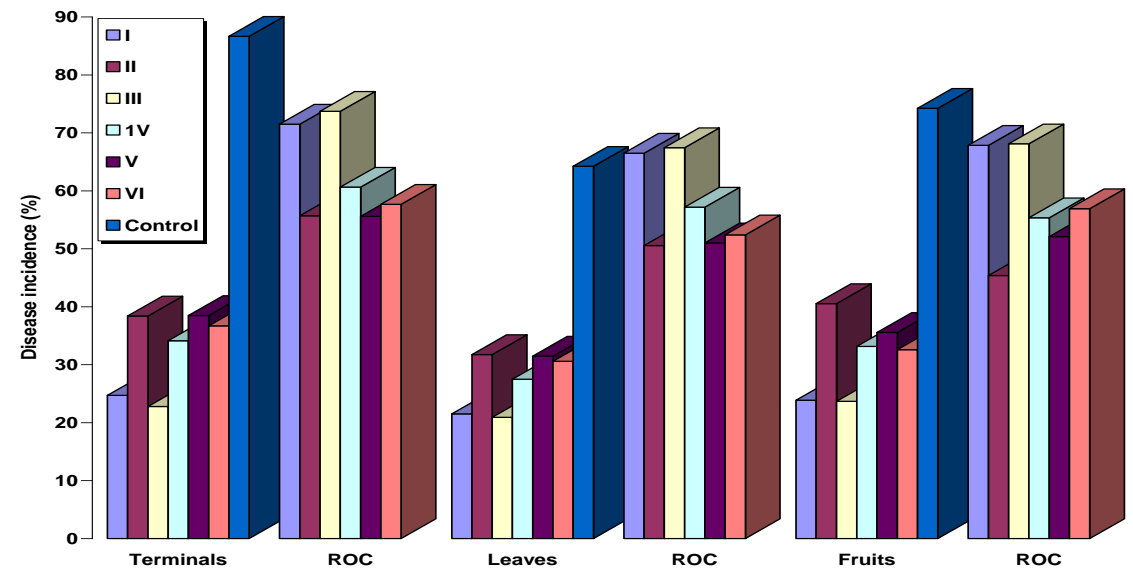

Fig.3 Effectiveness of different fungicidal spray schedules in controlling of primary and secondary scab infection of apple
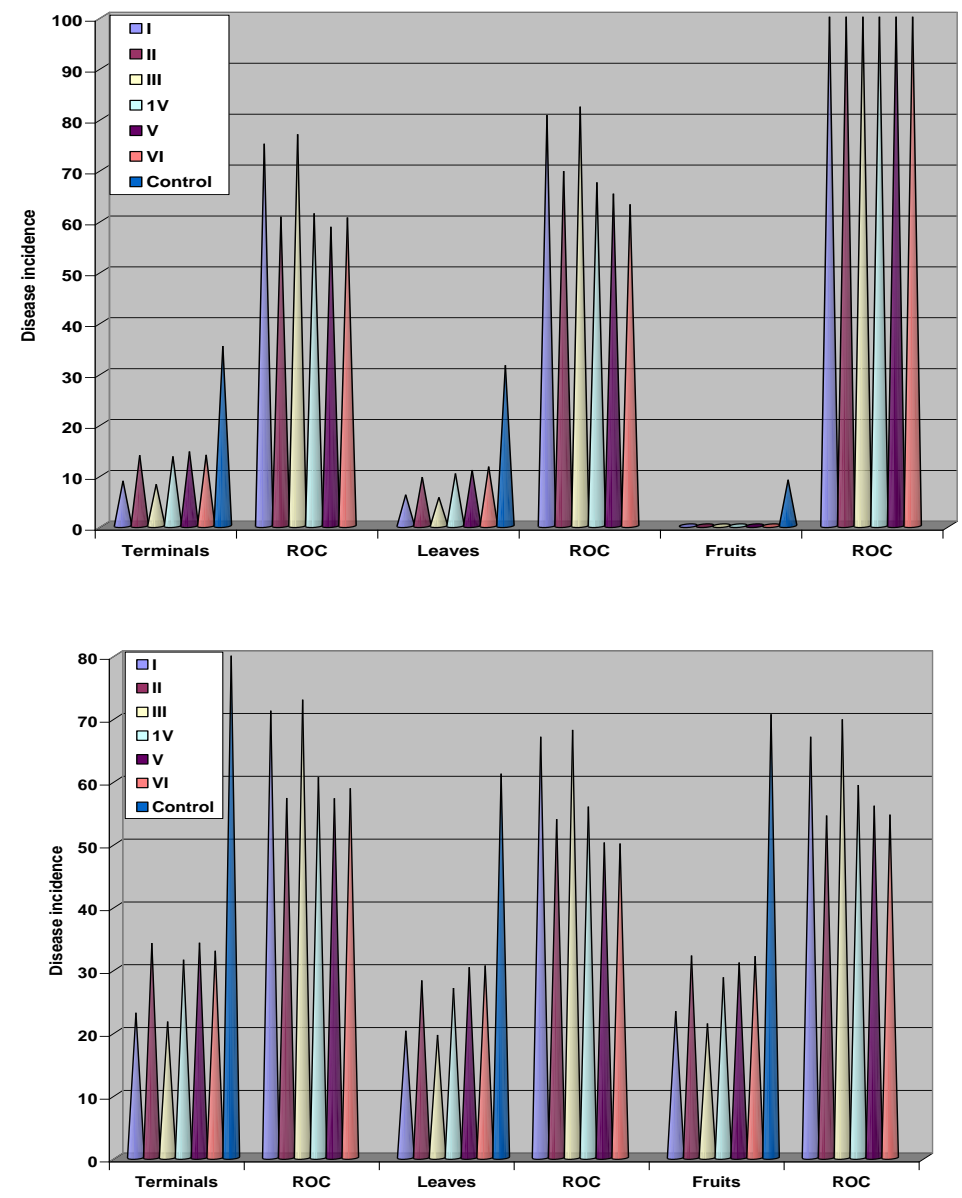
Fig.4 Effect of EBI fungicides spray schedule on the development of apple scab, a. disease incidence b. reduction over check
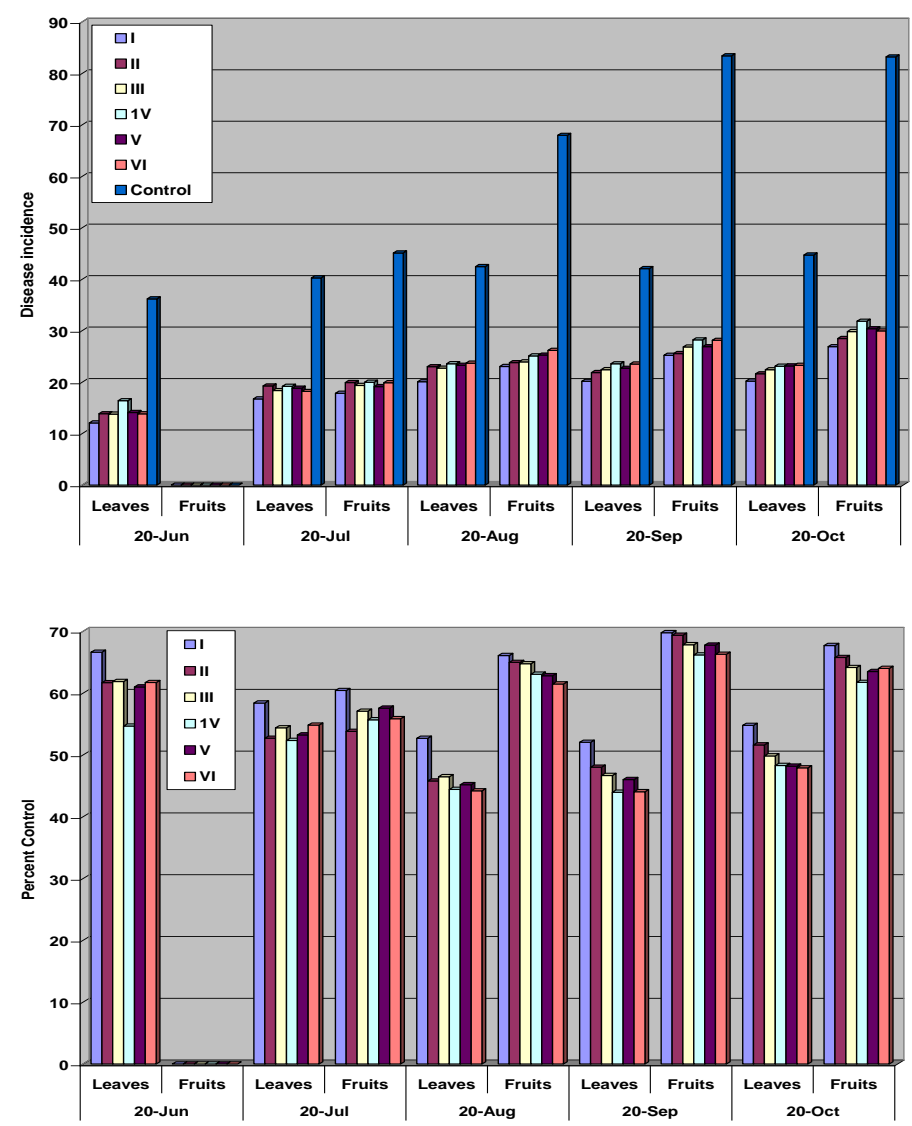

Protective efficacy of a new group of systemic fungicides known as ergosterolbiosynthesis inhibiting fungicides (EBI) were introduced which inhibit ergosterol biosynthesis and membrane function in fungi. Schwabe (1980a), Szkolnik (1981), and Schwabe and Jones (1983) reported that the EBI fungicides are week protectants, but these findings were contrary to those of Drandarevski and Schicke (1976), Brandes and Paul (1981), Gupta (1983) and Thakur and Gupta (1991, 1992a), Singh and Kumar, (1999), who reported EBI fungicides having good protective activity.

Based on the efficacy of different EBI fungicides in controlling apple scab disease, was evaluated for the efficacy of premature leaf fall, powdery mildew and sooty blotch. Obviously, protective sprays of Thiophanate methyl methyl + Mancozeb, Hexaconazole, Flusilazole, Penconazole, Carbendazim and Captan from pink bud through pre-harvest stage at 25 days interval effectively control the most of the foliage diseases in high altitude area of Gangotri fruit belt. The first spray of thiophanate methyl + mancozeb and $2^{\text {nd }}$ spray of hexaconazole or carbendazim were more effective in the suppression of symptoms development and sporulation of ascospore and conidia (powdery mildew), which is consistent with the earlier reports of Sharma and Sharma (1991b) and Singh, (2006) on effect of apple scab spray schedule on powdery mildew. The powdery mildew incidence was lowest when others sprays were given. Singh (2006) also observed that even one spray of carbendazim or thiophanate methyl at dormant or bud swell stage reduces the powdery mildew. In order to keep the 
disease under control the spray schedule must be strengthened with at least one mildewcide at dormant or bud swell stage. Jones et al., (1993) of Michigan State University, East Lousing had recommended the tank mixing a contact fungicides with the EBI fungicides could overcome problems of sub-optimum control of fruit scab and of pathogens not controlled by EBI fungicides. Under the severe conditions for disease in the test orchard, the tebuconazole-captan mixture gave excellent control of scab and sooty blotch. The contact fungicides captan, benomyl, mancozeb, metiram, and maneb are often tank mixed with EBI fungicides to increase the disease control of spectrum and to improve control of fruit scab and other diseases. In regions where sooty blotch is more severe than sulfer has not provided adequate control of this disease (Sutton and Brown, 1991), while mancozeb, captan, and benomyl were effective (Brown and Sutton, 1986; Sutton and Brown, 1988). Failure to control Marssonina blotch (pre-mature leaf fall) by captan was also reported several workers (Sharma and Gautam, 1997; Sharma and Kaul, 1997; Sharma 2001; Sharma and Verma, 2005). However, Takahashi and Sawamura, (1990) had recommended captan for its control. In our study, captan was also effective in different schedule for management of scab, powdery mildew, premature leaf fall sooty and flyspeck. However, the locally available fungicides were less effective and failed to give desired level of disease control in the field. Protective spray of newly developed EBI fungicides, hexaconazole, penconazole, defenconazole, and flusilazole, with early spray (pink bud) of systemic and non-systemic fungicides (carbendazim / mancozeb) were more effective but failed to give completely disease control in the field. As it seems to be problem of little importance in the developed countries, there is scant information on biology and epidemiology including control aspect (curative control with EBI fungicides) of above these diseases.

The present study is the first of its kind where spray recommendations were integrated to form combined spray schedules for the controlling major diseases in apple orchards. Based on the efficacy of different EBI and systemic and non-systemic fungicides in controlling the major diseases, san integrated spray schedules were evaluated for it efficacy at different locataion in Gangotri fruit belt of Distt. Uttarkashi. Obviously, protective sprays of mancozeb $(0.30 \%)$ or carbendazim $(0.05$ $\%)$ or thiophanate methyl $(0.05 \%)$ or carbendazim + mancozeb or thiophanate methyl + mancozeb at pink bud stage with EBI fungicides, hexaconazole $(0.03 \%)$, penconazole $(0.05 \%)$, flusilazole $(0.01 \%)$ defenconazole $(0.015 \%)$ and captan $(0.30 \%)$ or Zirum $(0.30 \%)$ from petal fall through pre harvest stage at 25 days interval effectively control the major diseases in Gangotri fruit belt. In the present day apple production system, fungicides sprays may be combined with insecticides, mites and foliar nutrients. Our approach is to suggest that apple production can not be done profitably without fungicides whose judicious and timely use in suitable spray schedules has obvious benefits in reducing environmental pollution and substantial benefits to the apple growers.

\section{References}

Brown, I. M. and Sutton, T. B. 1986. Control of Sooty blotch and Flyspeck of apple with, Captan, mancozeb, and mancozeb combined with dinocap in dilute and concentrated applications. Plant Dis. 70: 281-284.

Croxall, H. E., Gooynne, D. C. and Jenkine, J. E. E. 1952a. The rapid assessment of apple scab on leaves. Plant Pathol. 1: 3941.

Croxall, H. E., Gooynne, D. G. and Jenkine, J. E. E. 1952b. The rapid assessment of 
apple scab on fruits. Plant Pathol. 1: 8992.

Dar, G. N., Gupta, B. R., Azam, M. and Dhar, B. L 1983. Evaluation of fungicides against apple scab disease \{Venturia inaequalis (Cke.) Wint.\} under field conditions in Kashmir. Pesticide: 21-23.

Dar, G. N., Qadri, M. Y., Chani, M. V., Dhar, B. L. and Raina, P. K. 1981.Studies on relative efficacy of fungicides against apple scab (Venturia inaequalis) under field condition in Kashmir. Pestology 5: 5-7.

Drandarevski, C. A. and Schike, P. 1976. Formation and germination of spores forms Venturia inaequalis and Podoapora leucotricha following treatment with triforine. Z. Pflanzenkr Pflanzenschutz 3: 385-396.

Gupta, G. K. 1983. Behavior of fungicides and various spray schedules in the control of apple scab (Venturia inaequalis). International J.Tropical Pl.t Dis. 1: 181185.

Gupta, G. K. and Lele, V. C. 1980 a. Prevalence, distribution and intensity of apple scab in Kashmir valley. Indian J. Agric. Sci. 50: 45-50.

Gupta, G. K. and Lele, V. C. 1980. Role of urea in suppression of ascigerous stage and comparative in vitro efficacy of fungicides against apple scab. Indian $J$. Agric. Sci. 50: 167-173.

Hoch, H. C and Szkolnik, M. 1979. Viability of Venturia inaequais chlorotic fleckes resulting from fungicides application to infected Malus leaves. Phytopathology 69:456-462.

Jones, A. L., Ehret, G. R., El-Hadidi, M. E. Zabik, M. J., Cash, J. N. and Johnson, J. W. 1993. Potential for zero residue disease control programs for fresh and processed apples using sulfur, Fenarimol, and Myclobutanil Plant Dis. 77:147-151.

Kloes, E. J., Chevalier, J. and Lovalley, D. 1982. Fungicide and Nemeticide test result of 1981. 37: P 8-9.

Mckinney, H. H. 1923. Influence of soil temperature and moisture on infection of wheat seedling by Helminthosporium sativum. J. Agric. Res. 26:195-217.

Ross, R. G. 1982. Fungicide and Nemeticide test result of 1981. 37: 15.

Schwabe, W. F. S and Jones, A. L. 1983. Apple scab control with bitertanol as influenced by adjuvant addition. Plant Dis. Reprt. 65: 992-994.

Schwabe, W. F. S. 1980. Curative activity of fungicides against apple scab infection of Venturaia inaequalis (Cke.) Wint. Phytophylactica 12: 199-207.

Schwabe, W. F. S. 1980a. Wetting and temperature requirement for apple leaf infection by Venturia inaequalis in South Africa. Phytophylactica 12: 69-80.

Sharma, J. N. 2001. Diagnosis and control of premature leaf fall problems in apple. $J$. Mycol. Pl. Pathol. 31: 305-310. Sharma, J. N. and Kaul, J. L. 1997. Marssonina blotch a new disease hits apple crop in Himachal Pradesh. Indian Phytopathological Society.

Sharma, J. N. and Gautam, D. R. 1997. Studies on premature leaf fall in apple - A new problems. Indian J. Pl.Prot. 25: 8-12.

Sharma, J. N. and Kaul, J. L. 1997. Marssonina blotch a new disease hits apple crop in Himachal Pradesh. Indian Phytopathological Society.

Sharma, J. N. and Verma, K. D. 2005. Integrated management of foliar and fruit diseases of apple scab in Himachal Pradesh, Indian J. Mycol. Pl. Pathol. 35: 48-52.

Sharma, R. L. and Kaul, J. L. 1982. Effect of post-harvest fungicidal treatment in controlling olive anthracnose. Indian Phytopathol. 45: 128-130.

Sharma, V. P. and Sharma, S. K. 1991. Impact of apple scab spray schedule on the Control of Sooty blotch and flyspeck diseases. Plant Dis. Res. 5: 198-199.

Sharma, V. P. and Sharma, S. K. 1991b. Effect of apple scab spray schedules on Powdery mildew and alternaria leaf spot. Indian J. Mycol. Pl. Pathol. 21: 190 191.

Singh K. P. 2006. Investigation on development 
of bio-control measures for the management of saprophytic stage of apple scab pathogen Venturia inaequalis in Uttaranchal Himalayas. ICAR, Report New Delhi, 53pp.

Singh, A. 2006. Epidemiology and management of apple powdery mildew in the Uttaranchal Himalayas. Ph. D. Thesis, HNBGU Srinagar, Uttaranchal 221pp.

Singh, K. P. and Kumar, J. 1999. Efficacy of different fungicidal spray schedules in combating apple scab severity in Uttar Pradesh Himalayas. Indian Phytopathol. 52: 142-147.

Singh, K. P. and Kumar, J. 2005. Integrated pest management of apple scab GBPUA\&T Tech. Bulletin p 34.

Singh, K. P. and Kumar, J. 2006. Integrated management of apple scab, through development of scab warning system in Uttaranchal. NATP-CGP Reprt. ICAR, New Delhi, 46.pp.

Sutton. B. and Brown, E. M 1988. Disease control on Golden Delicious, 1987. Fungicides Nemeticide Test 43: 42.

Sutton. B. and Brown, E. M 1991. Disease control with sulfur and standard recommendation, 1990. Fungicides Nemeticides Test 46: 39.

Szkolnik, M. 1981. Physical modes of action of Sterol-inhibiting fungicides against apple diseases. Plant Dis. 65:981-985.

Takashashi, S. and Sawamura, K. 1990. Marssonina blotch In: Compendium of Apple and Pear Diseases (Jones, A. L., and Aldwinckle, H. S. eds.) APS Press
St. Paul Minnesota.60-63pp.

Thakur V. S. 1992. Apple scab menace to apple bowl. Kisan World 48-49.

Thakur, V. S. 1987. Studies on the effect of fungicides on apple scab Venturia inaequalis (Cke.) Wint. Pathogenesis. Ph.D Thesis, University of Horticulture and Forestry Solan, India, 136pp.

Thakur, V. S. and Gupta, G. K. 1990b. Note on development of spray schedules for controlling apple scab in Himachal Pradesh, Indian J. Hortic. 47: 60-63.

Thakur, V. S. and Gupta, G. K. 1991. Studies on the effect of Sterol-inhibitors on apple scab Venturia inaequalis pathogenesis. Indian J. Plant Prot. 19: 185-190.

Thakur, V. S. and Gupta, G. K. 1992a. Curative and protective action of ergosterol biosynthesis inhibiting fungicides in relation to infection period in the control of apple scab. Pestology 16: 32-37.

Thakur, V. S. and Gupta, P.K. 1991. Apple phylloplane microbes as antagonists to Venturia inaequalis. Indian Phytopathol. 44: 34 (Abstr.).

Thakur, V. S. and Sharma, R. D. 1999. Effect of urea on microbial degradation of apple leaf litter and its relationship to the inhibition of pseudothecial development of Venturia inaequalis. Indian J. Agril. Sce. 69: 147-151.

Turner, B. and Sutton, T. B. 1982. Fungicides and Nemeticide test results of 1981. 37: 16.

\section{How to cite this article:}

Prasad, R. K., K. P Singh and Gupta, R. K. 2020. Development of Spray Schedules for Controlling Apple Scab in Uttarakhand. Int.J.Curr.Microbiol.App.Sci. 9(10): 2894-2908. doi: https://doi.org/10.20546/ijcmas.2020.910.349 